(3) Is it true that we are now workmen from the point of view of being "proceeded against" and not workmen from the point of view of arbitration?

(4) The B.M.A. is not a trade union and is, therefore, not included in Order No. 1376. Was it omitted by accident or design ?

(5) What happens if a dispute arises within this Order ? (Or are we waiting to consider this point until a dispute actually does arise ?)

Both these are negative Orders, having the force of law if not annulled within 40 days. There are, therefore, 36 days from the summoning of the new Parliament in which effective action may be taken. Failing effective action, surely withdrawal from the Service is our only alternative. The issue is as important as that in the minds of some of us. What do our leaders think? Do we not deserve to be told ?-I am, etc.,

Winchester.

\section{Ronald Gibson.}

** The Secretary of the Association writes: The position arising from the publication of S.I.s 1373 and 1376 was reported to the Council on September 26, the earliest occasion on which Counsel's opinion on their meaning was available. Prayers to annul an order in the House of Commons must be lodged within 40 days of its publication and while Parliament is in session. Parliament was then in recess and is now dissolved. Thus no Parliamentary action was possible or will be possible until the new Parliament assembles. Council has appointed an ad hoc committee with authority to take appropriate and timely action.

\section{Remuneration and the Small List}

SIR,-I wish to protest strongly at the sentiments expressed in Dr. H. Bergh's letter (Supplement, September 22, p. 122). Your correspondent seems to be somewhat out of touch with present-day conditions, otherwise he would not write such arrant nonsense about the advisability for young doctors to become junior partners or to take a death vacancy. The virtual impossibility of entering into a partnership unless one pays vast sums for a house, instruments, etc., is well known to everybody interested in the matter-not to speak of the enormous number of applicants for every death vacancy.

As to the way in which he takes it upon himself to call "squatting" practitioners robbers and to imply that they debase our professional ethical ideals, I think these remarks should be treated by all fair-minded people with the contempt they deserve.-I am, etc.,

London, W.12.

A. MeYer.

\section{POINTS FROM LETTERS}

\section{Large Lists}

Dr. A. H. Levers (Leigh-on-Sea) writes: I was very interested in the letter signed by "Megalist" (Supplement, September 8, p. 109). Where I take issue with him is in the latter part of his letter. This shows clearly why there is no unity in the medical profession - a fatal non-unity which has put the general practitioners in their present position, a position most of us dislike. This latter part of his letter means, and could be written, "Should the necessity for resignation ever arise, my fellows can hardly expect $m e$ to take any financial risk even though the majority, being underpaid, are at risk all the time. I cannot be expected to support my colleagues in their efforts to rescue medical practice from its present unsatisfactory position, but will share in any benefits they secure."

\section{The New Doctoring}

Dr. G. L. Davies (Brighton) writes: A woman who came to my surgery the other evening consulted me not only about herself but about six other members of her family. . . . She finally departed with a handful of prescriptions, leaving unaccomplished what was presumably the chief part of her mission-namely, an attempt to find out the cause of her daughter-in-law's infertility.

\section{Association Notices}

\section{MIDDLEMORE PRIZE}

The Middlemore Prize, which consists of a cheque for $£ 50$ and an illuminated certificate, was founded in 1880 by the late Richard Middlemore, F.R.C.S., of Birmingham, to be awarded for the best essay or work on any subject which the Council of the British Medical Association may from time to time select in any department of ophthalmic medicine or surgery. The Council of the British Medical Association is prepared to consider an award of the prize in the year 1952 to the author of the best essay on "The Influence of Heredity in Glaucoma," or "The Influence of Heredity in Cataract."

Essays submitted in competition must reach the Secretary, British Medical Association, British Medical Association House, Tavistock Square, London, W.C.1, on or before December 31, 1951. Each essay must be signed with a motto and accompanied by a sealed envelope marked on the outside with the motto and containing the name and address of the author. In the event of no essay being of sufficient merit, the prize will not be awarded in 1952.

\section{Diary of Central Meetings} OCTOBER

23 Tues. Finance Committee, 10.30 a.m.

23 Tues. Joint Formulary Committee, 2 p.m.

23 Tues. Physical Medicine Group Committee, 2 p.m

23 Tues. Special Finance Inquiry Committee, 2 p.m.

24 Wed. Joint Meeting of Journal Committee and Publishing Subcommittee, 10.30 a.m.

24 Wed. Occupational Health Committee, 2 p.m.

24 Wed. United Kingdom Members of the Arrangements Committee, 4.30 p.m

26 Fri. Library Subcommittee, Science Committee, 12 noon.

26 Fri. Pathologists Group Committee, 2 p.m.

26 Fri. Science Committee, 2 p.m.

29 Mon. Committee of Reference, 10.30 a.m.

31 Wed. Annual Conference of Representatives of Local Medical Committees, 10 a.m.

Branch and Division Meetings to be Held

Bournemouth Division.-At Ballroom, Royal Bath Hotel, Friday, October 26, 7.30 for 8 p.m., annual dinner.

Brighton Division.-At Dudley Hotel, Hove, Tuesday actobe: $23,8.30$ p.m., annual meeting, adoption of new Ethical Rules; 9.15 p.m., Dr. Robert Forbes. "The Legal Hazards in Medical Practice."

Coventry Division.-At Coventry and Warwickshire Hospital, Tuesday, October 23, 8.30 p.m., clinical meeting. Talk by Dr. W. P. Elford: "Seborrhoeic Eczema, Acne Vulgaris, and Rosacea." A discussion will follow.

OxFord Division.-At Radcliffe Infirmary, Oxford, Wednesday, October 24, 8.15 p.m. Professor L. J. Witts: "The Physiology and Therapeutic Effects of Cortisone and A.C.T.H." Preceded by a special meeting to adopt the revised Ethical Rules.

Tower Hamlets Division.-At St. Andrew's Hospital, Bow, London, E., Friday, October 26, 3 p.m., clinical meeting. Pathological demonstration by Dr. Louis Steingold.

West Suffolk Division.-At Everard's Hotel, Tuesday, October 23, 8.30 p.m., annual B.M.A. lecture by Dr. W. R. Bett : "The Pathology of Genius."

Wigan Division.-At The Hollies, Wigan Lane, Wigan, Thursday, October $25,8.15$ p.m., annual general meeting, adoption of new Ethical Rules, etc.

Correction.-An error occurred in publishing subsection $28(d)$ of the First Interim Report of the Council on the Reform of the National Health Service (Supplement, October 13, p. 144). It should read: Section 66 of the National Health Service Act, 1946 empowers the Minister to prescribe by regulation the terms of service of general practitioners and Section 33 to make provision for the issue of an unlimited number of certificates without payment. 